\title{
Bryophyte communities across the ecological succession process in the Caxiuanã National Forest, Pará, Brazil
}

\author{
TÁSSIA T.G. TAKASHIMA-OLIVEIRA, PRISCILA S. DE MEDEIROS \& ANA CLÁUDIA C. \\ TAVARES-MARTINS
}

\begin{abstract}
Bryophytes play an important role in the process of ecological succession: conditioning the environment favourably for the emergence of subsequent groups. The objective of this study was to investigate the distribution of bryophyte communities in a cronossequence in the Caxiuanã National Forest, Pará, Brazil. To this end, biological material was collected in forest remnants with different successional stages based on regeneration age: Stage I ( 0 - 10 years), Stage II (10 - 25), Stage III (> 25) and Stage IV (primary forests). Density, richness and composition of species were compared between successional stages and the occurrence of possible indicator-species was investigated. The identified taxa were also classified by guilds of tolerance to solar radiation and colonized substrate. Composition of species was the variable that most contributed to understanding the distribution of bryophyte communities throughout successional stages, with eight species identified as potential indicators of some successional stages. Generalist species predominated in all stages. The richness of sun tolerants, in turn, decreased with the progress of succession, while shade tolerants increased. The land use history and land cover can influence the availability and quality of substrates and consequently their colonization by bryophytes in the different stages.
\end{abstract}

Key words: Amazon rainforest, cryptogams, forest regeneration, secondary forest.

\section{INTRODUCTION}

Anthropological disturbances in tropical forests, no matter the extent, cause changes in the dynamics of the established communities (Chazdon 2008, Machado et al. 2017). After the deterioration and abandonment of disturbed areas, the process of spontaneous regeneration starts to reestablish the dynamic equilibrium of a mature forest (Chazdon 2012). Secondary forests emerge in the interim process as fundamental for biodiversity protection and maintenance in terms of both structure and functionality of ecosystem services (Vieira \& Gardner 2012).
The dynamics of secondary succession in tropical rainforests follows a progression of stages in which there is a gradual increase of taxonomic richness as well as structural and functional complexity of the forest (Chazdon 2012, Salomão et al. 2012). Chazdon (2008) classified secondary succession into three stages, according to regeneration time. Therefore, the author considered a set of parameters such as seed germination, species recruitment and ecological groups. In this classification, the first successional stage is characterized by the dominance of species tolerant to high solar incidence such as herbaceous plants, shrubs and woody lianas; after 10 years, the considerable 
change in structure and composition of the vegetation resulting from the colonization of tree species characterizes the second stage; and in the third stage, after 25 years of regeneration, the forest presents a greater degree of structural complexity, with formation of forest strata, heterogeneous distribution of light in the understory, and mortality of shade-intolerant species (Chazdon 2008).

Recolonization of secondary forests is faster than structural transformations of the successional landscape in some biological groups such as edaphic macrofauna. In that case, after a period of 7 to 8 years postdisturbance, the composition of secondary forests has been reported to resemble that of primary forests (Medeiros 2016, Amazonas et al. 2018). In contrast, 40 years of regeneration in a shrubbery forest were not enough to provide environmental conditions to reestablish the original diversity of epiphytic macrolichens lost due to disturbances in a tropical montane forest in southern Ecuador (Benitez et al. 2012). In the case of bryophytes, studies in secondary forests in the Brazilian Amazon revealed lower bryophyte richness than primary forests (IlkiuBorges \& Lisboa 2002, Tavares-Martins et al. 2014, Fagundes et al. 2016).

Anthropic disturbances in native forests cause the decline of extreme desiccation sensitive (shade tolerant) bryophytes, as well as the emergence and permanence of those more resistant to environmental variations (sun tolerants and generalists, respectively) (Acebey et al. 2003). Desiccation tolerant taxa have an important ecological role in the succession process because they favorably affect soil development in newly altered environments (Ariyanti et al. 2008). As these species retain water, bind erosion-prone soil particles into more stable soil aggregates, and fix nitrogen, they aid in the arrival and permanence of subsequent ecological groups (Glime 2007).

Although the distribution of bryophytes is strongly influenced by limiting factors such as high light incidence and low humidity, the availability and quality of woody debris and the continuity of woody vegetation also influence the occurrence of this group (Lesica et al. 1991). Bryophytes can colonize different substrates such as soil, rocks, trunks and leaves (Robbins 1952).

The Caxiuanã National Forest (FLONA) consists of a conservation unit that holds a large extension of continuous forest (Lisboa et al. 2013). However, because it is a protected area of sustainable use, it allows the use of land for the subsistence of traditional populations established there. The main uses of natural resources are hunting, fishing, logging and family farming, in this activity, the cutting and burning vegetation for soil preparation and cultivation is a common practice of cultural treatment. After soil wear by repeated harvests, these areas are abandoned, resulting in the formation of a mosaic of secondary forests in the Caxiuanã FLONA (Chazdon 2012, Massoca et al. 2012).

Thus, ecological studies are necessary to know what the contributions of bryophytes to the structure and functionality of secondary forests in the Caxiuanã FLONA. In this study, we intended to answer the following questions: (1) How do bryophyte density, richness and composition diverge across successional stages in the Caxiuanã National Forest? (2) Are there potential indicator species of successional stages? (3) How does the distribution of the desiccation tolerance guilds and the occupation of the species occur in the substrates in the different successional stages?

The objective of this study was to investigate the structural characteristics and successional indicator species in bryophyte communities 
in a cronossequence in the Caxiuanã National Forest, Pará, Brazil.

\section{MATERIALS AND METHODS}

The study was conducted in the Caxiuanã National Forest (FLONA), located in the municipalities of Melgaço and Portel, in the state of Pará, Brazil. This is a federal conservation unit for sustainable use created by the Decree no 239 of November 28, 1961 (Brasil 1961).

The area is in the tropical belt and has climate of Am type (tropical humid) according to Köppen's classification, with mean annual temperature of $26^{\circ} \mathrm{C}$, annual rainfall around 1,717 $\mathrm{mm}$, and relative air humidity around 80 percent (Lisboa 2013). It is located in a lowland area, with altitudes below $50 \mathrm{~m}$ and typical extensive and tabular interfluves with predominance of yellow latosols (Lisboa 2013).

Bryophytes were sampled in July 2016 in 20 plots of $20 \times 20 \mathrm{~m}\left(400 \mathrm{~m}^{2}\right)$ placed in the understory of primary and secondary nonflooded forests. The delimitation of plots following the recommendations of Frahm et al. (2003) with adaptations of the dimension of Medeiros (2016) for systematic collection in small areas, where all substrates available for colonization of bryophytes were sampled according to their representativeness within each plot of 400 square meter. The plots were distributed in areas with different successional stages (five plots per stage) according to the classification proposed by Chazdon (2008) with adjustments to primary forests, which were classified here as Stage IV (Table I). Thus, Stage I (0 - 10 years of regeneration) corresponds to the stand initiation phase; Stage II (10 - 25 years) to the stem exclusion phase; Stage III (> 25 years) to the understory stand re-initiation phase; and Stage IV to primary forests (Table I).
Biological material was collected inside the whole area delimited by each plot and methodological procedures of collection, herborization and preservation followed (Yano 1984). Specialized literature was used for identification of species (Gradstein 1994, Reiner-Drehwald 2000, Buck 2003, Gradstein \& Costa 2003, Zartman \& Ilkiu-Borges 2007, Dauphin 2009, Gradstein \& Ilkiu-Borges 2009) and the classification system adopted for Marchantiophyta and Bryophyta were (CrandallStotleretal.2009, Goffinetetal.2009), respectively, with adaptations of consider (Carvalho-Silva et al. 2017) for Sematophyllaceae. Vouchers of the analyzed material were incorporated into the collection of the Herbarium Prof. Dr. Marlene Freitas da Silva (MFS).

Species were classified as to guild of tolerance to solar radiation: sun tolerants, shade tolerants and generalists. This classification was based on the works of (Richards 1984, Cornelissen \& ter Steege 1989, Gradstein 1992, 1994, Gradstein et al. 2001, Gradstein \& IlkiuBorges 2009, Tavares-Martins 2009, Santos et al. 2011, Garcia et al. 2014b, Fagundes et al. 2016). Species were also classified according to the colonized substrate into epiphyllous, epixylic, corticicolous and terrestrial (Robbins 1952), with adaptations for colonization of termite mounds and coal.

Differences between the dependent variables (species density and richness) and successional stages (one-way ANOVA) were tested in the Past 3.18 software (Hammer et al. 2013) considering plots as sample units. Therefore, we used the term individuals for the mean number of bryophytes occurrence at each stage.

Differences in the species composition of the four successional stages and of colonized substrates were tested by Multivariate Analysis of Variance (MANOVA) with the Bray Curtis similarity 
Table I. Characterization of collection plots and distribution of the number of samples per ecological successional stage according to the regeneration time in the Caxiuanã National Forest, Pará, Brazil.

\begin{tabular}{|c|c|c|c|c|}
\hline Stage & Phase & Description & $\begin{array}{c}\text { Plots } \\
\text { (Sample unit) }\end{array}$ & Age of regeneration \\
\hline \multirow{5}{*}{1} & \multirow{5}{*}{$\begin{array}{l}\text { Initiation }(0-10 \\
\text { years) }\end{array}$} & \multirow{5}{*}{$\begin{array}{l}\text { Seed germination, mortality } \\
\text { of herbaceous species and } \\
\text { colonization of pioneer species }\end{array}$} & $\mathrm{CPI}-1$ & 2 \\
\hline & & & $\mathrm{CPI}-2$ & 3 \\
\hline & & & CPI-3 & 4 \\
\hline & & & $\mathrm{CPI}-4$ & 6 \\
\hline & & & CPI-5 & 8 \\
\hline \multirow{5}{*}{ II } & \multirow{5}{*}{$\begin{array}{l}\text { Stem exclusion ( } 10 \\
-25 \text { years) }\end{array}$} & \multirow{5}{*}{$\begin{array}{c}\text { Canopy densification and } \\
\text { formation of strata, as well as } \\
\text { high mortality of lianas and } \\
\text { shrubs }\end{array}$} & CPII-1 & 12 \\
\hline & & & CPII-2 & 14 \\
\hline & & & CPII-3 & 16 \\
\hline & & & CPII-4 & 20 \\
\hline & & & CPII-5 & 25 \\
\hline \multirow{5}{*}{ III } & \multirow{5}{*}{$\begin{array}{c}\text { Resurgence of the } \\
\text { sub-forest }(>25 \\
\text { years) }\end{array}$} & \multirow{5}{*}{$\begin{array}{l}\text { Heterogeneous distribution of } \\
\text { luminosity in the understorey, } \\
\text { mortality of pioneer species, } \\
\text { predominance of long-lived taxa } \\
\text { and reproductive maturity of } \\
\text { shade-tolerant species }\end{array}$} & CPIII-1 & 30 \\
\hline & & & CPIII-2 & 30 \\
\hline & & & CPIII-3 & 40 \\
\hline & & & CPIII-4 & 40 \\
\hline & & & CPIII-5 & 40 \\
\hline \multirow{5}{*}{ IV } & \multirow{5}{*}{ Primary forests } & \multirow{5}{*}{$\begin{array}{l}\text { Mature forest with no history of } \\
\text { anthropogenic disturbance }\end{array}$} & FP-1 & - \\
\hline & & & FP-2 & - \\
\hline & & & FP-3 & - \\
\hline & & & $\mathrm{FP}-4$ & - \\
\hline & & & FP-5 & - \\
\hline
\end{tabular}

index (Zar 2009). We used Multidimensional Non-Metric Scaling (NMDS) for ordination of groups, a method based on a distance matrix in which the algorithm seeks to find data points in two or more dimensions (Legendre \& Legendre 2012). The Sorensen index was used as a distance measure, with better spatialization in two dimensions and criterion for stabilization $=$ $0.000,001$ in the Primer-Permanova software.

Possible indicator species of each successional stage were determined by the Indicator Species Index (IndVal) in the R software. This analysis evaluates the fidelity and specificity of each individual species to a particular group, in the present case successional stage (Dufrêne \& Legendre 1997).

For the analysis of the distribution of the number of species regarding the guild of tolerance to solar radiation within the stages, descriptive statistics (average per guild) were performed. E, for substrate colonization at each succession stage, was the relative distribution, calculated on the basis of the number of occurrences in the plot by a given substrate by the total occurrence number of the same substrate, considering all plots. 


\section{RESULTS}

The bryophyte flora in the chronosequence analyzed in primary and secondary non-flooded forests in the Caxiuanã FLONA was composed of 133 species, distributed in 1,292 occurrences (Supplementary Material, Table SI).

In the Stage I (stand initiation phase), 53 occurrences of 29 species were recorded in each plot; in the Stage II (strata formation phase), 70 occurrences of 37 species were recorded; in the Stage III (understory re-initiation phase), 73 occurrences of 35 species were recorded; and in the Stage IV, 62 occurrences of 35 species were recorded (Table $\mathrm{II}$ ). There were no statistically significant differences between successional stages in terms of richness $(F=1.35, p=0.20)$ or density $(F=1.65, p=0.22$ ).

A significant difference in the species composition of successional stages was observed (Pseudo-F $=3.13, p<0.001$ ). The posthoc test showed that Stage I differed significantly from the other stages $(p<0.01)$ and that stages II and IV also differed from each other $(t=1.29$, $p<0.01)$. The distinctions between stages are portrayed in the NMDS ordination (Figure 1).

Eight species were indicators of different successional stages according to the IndVal test. Archilejeunea auberiana (Mont.) A.Evans., Acrolejeunea torulosa (Lehm. \& Lindenb.) Schiffn. and Acrolejeunea emergens (Mitt.) Steph. were indicators of Stage I; Cololejeunea subcardiocarpa Tixier of Stage II; and Prionolejeunea denticulata (Weber) Schiff., Prionolejeunea muricato-serrulata (Spruce) Steph., Radula flaccida Lindenb. \& Gottsche and Haplolejeunea cucullata (Steph.) Grolle of Stage IV. There were no indicator species for the Stage III.

Table II. Mean density and richness of bryophyte species per plot across successional stages in the Caxiuanã FLONA, Pará, Brazil.

\begin{tabular}{|c|c|c|}
\hline Successional stages & Species density & Species richness \\
I & 53 & 29 \\
\hline II & 70 & 37 \\
\hline III & 73 & 35 \\
\hline IV & 62 & 35 \\
\hline
\end{tabular}

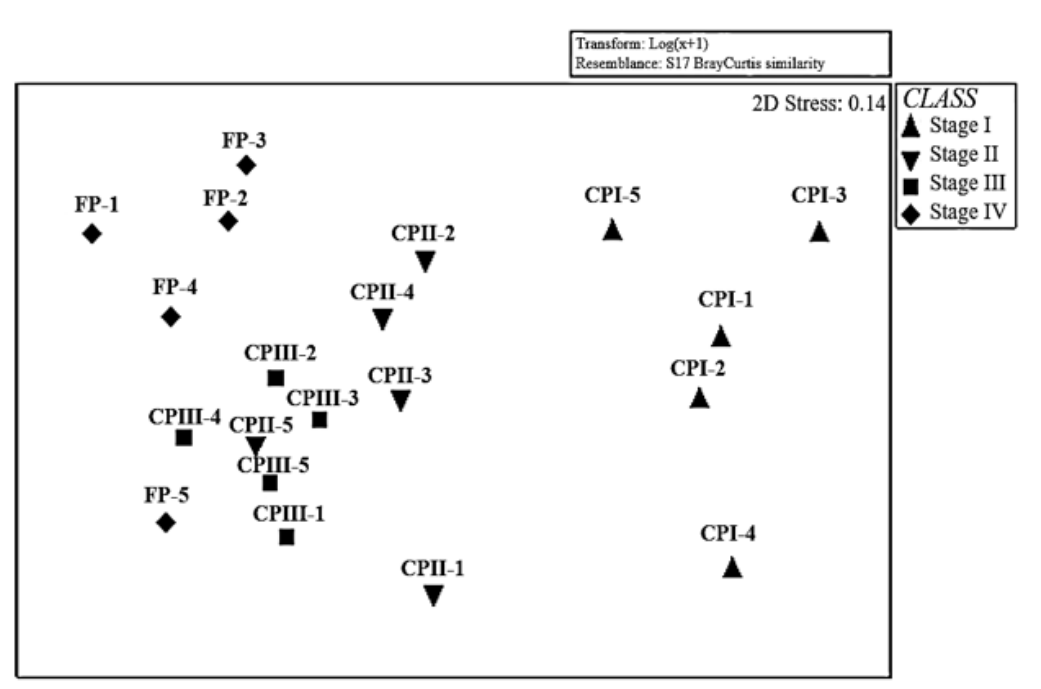

Figure 1. Multidimensional Non-Metric Scaling (NMDS) of bryophyte species composition across the four successional stages in the Caxiuanã FLONA. 
As for guild of tolerance to solar radiation, seven sun tolerants, two shade tolerants and 20 generalists occurred in Stage I; six sun tolerants, six shade tolerants and 22 generalists in Stage II; four sun tolerants, six shade tolerants and 24 generalists in Stage III; and four sun tolerants, nine shade tolerants and 19 generalists in Stage IV (Figure 2). Among the 136 species identified, 13 were not classified into any category of tolerance to solar radiation.

In terms of colonized substrates, bryophytes were found colonizing mainly live trunks (70\%, 895 occurrences and 115 spp.), followed by deadwood (16\%, 206 occurrences and 74 spp.), leaves (11\%, 149 occurrences and 28 spp.), coal (2\%, 20 occurrences and 11 spp.), termite mounds (1\%, 14 occurrences and 8 spp.), and soil (1\%, 9 occurrences and 8 spp.).

Bryophyte communities had a significantly different composition across colonized substrates (Pseudo-F $=4.14, p<0.001$, Figure 3). The post-hoc test revealed a different composition of the epiphyllous community in relation to all the other analyzed substrates ( $t$ $>1.76, p<0.002$ ). There were also differences between the composition of species colonizing coal versus termite mounds $(t=1.48, p=0.02)$, coal versus soil ( $t=1.49, p<0.05)$, and live trunks versus deadwood $(t=1.69, p=0.0001)$.

Corticicolous species presented a distribution ranging from 20 to 30 percent in the different stages (Figure 4). Epixylic species were poorly represented in Stage I (9\%) and the epiphyllous in Stage III (10\%). Species found on soil were more frequent in Stage I (56\%), and species colonizing termite mounds and coal occurred only in the stages I, II and III, gradually increasing with the progress of successional stages.

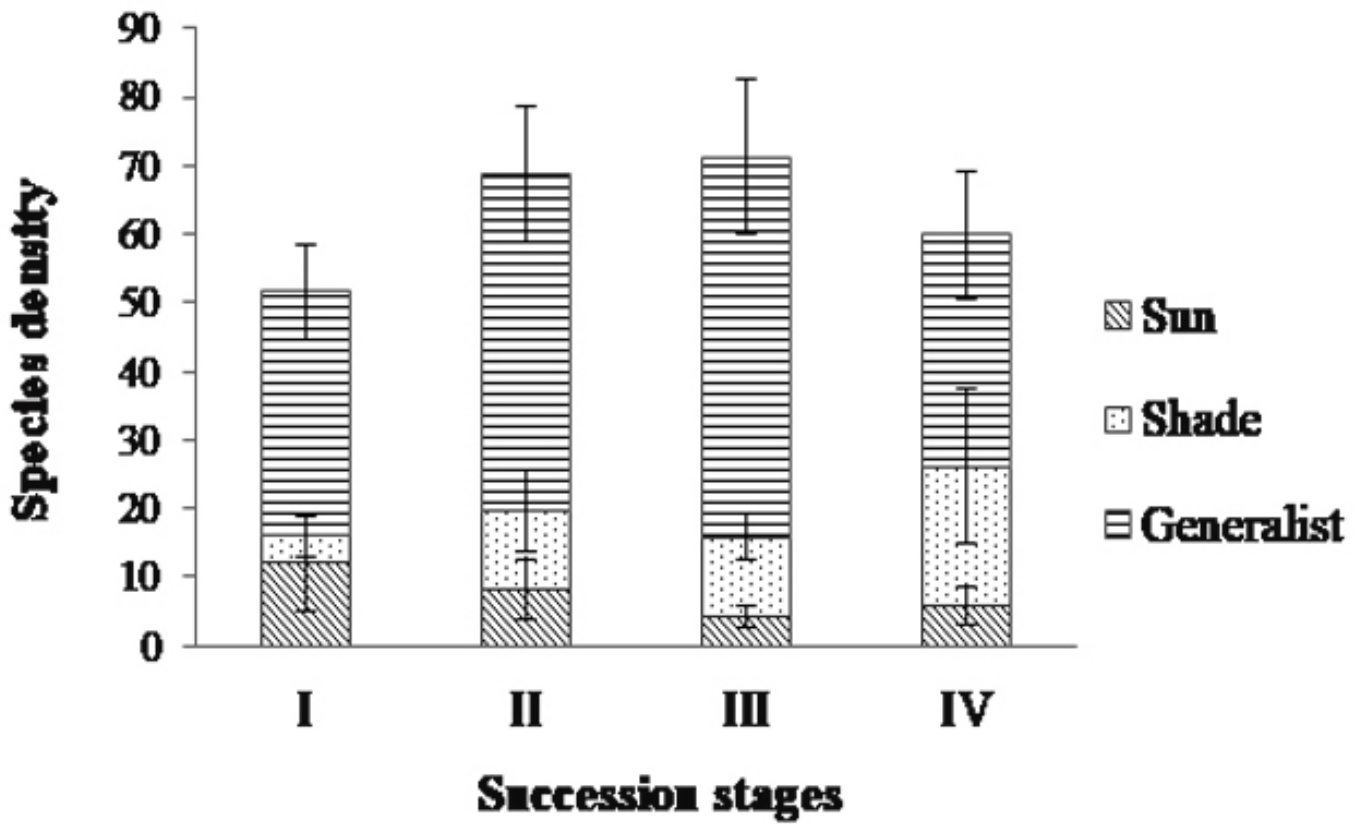

Figure 2. Distribution of bryophyte species into desiccation tolerance guilds across different successional stages in the Caxiuanã FLONA, Pará, Brazil. 


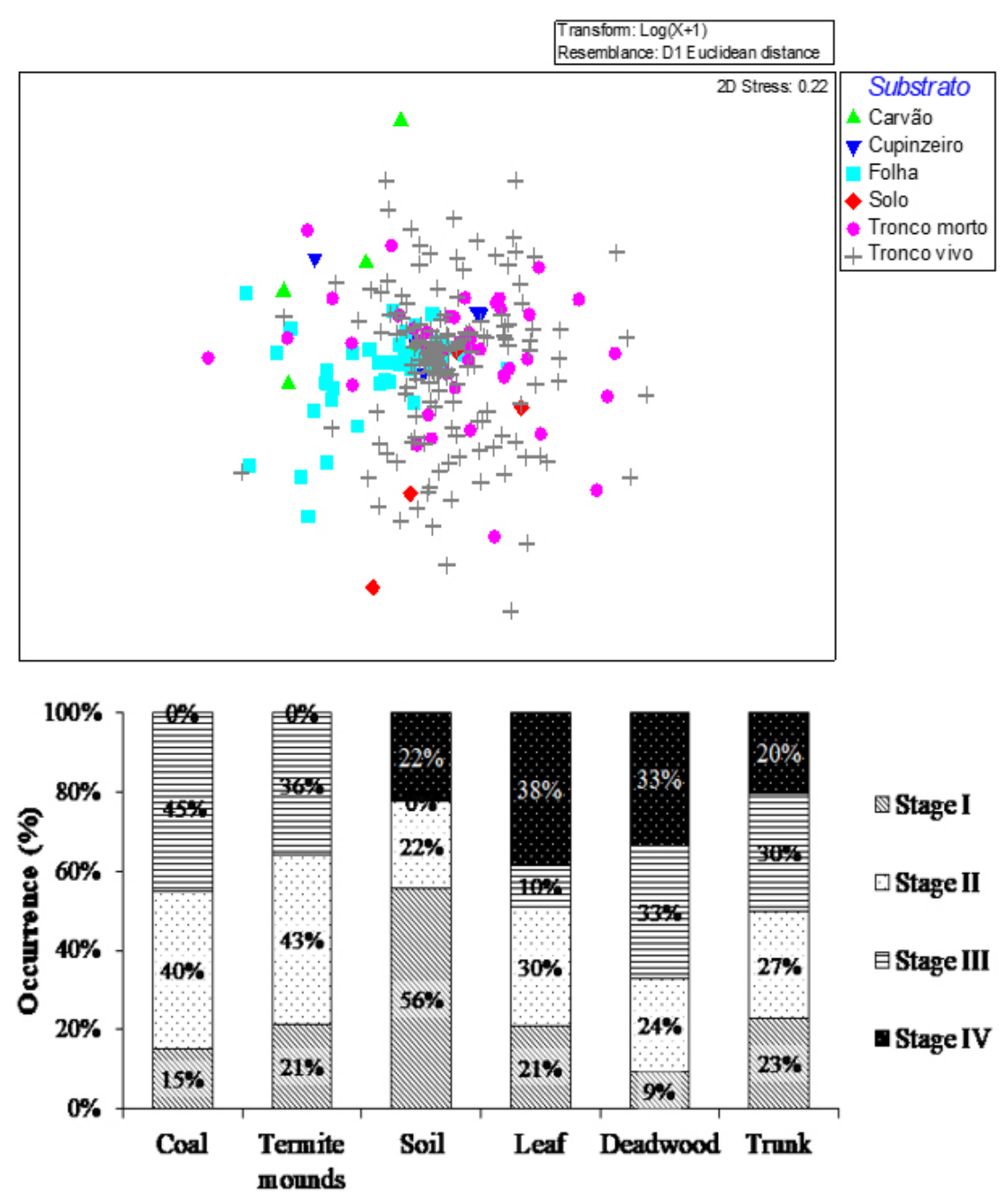

Figure 3. Multidimensional Non-Metric Scaling (NMDS) of bryophyte species composition of colonized substrates in the Caxiuanã FLONA.

\section{DISCUSSION}

\section{Species density and richness}

The recorded bryophyte flora represents about 22 percent of the richness registered in the Brazilian Amazon, 33 percent in the state of Pará (Costa \& Peralta 2015) and 61 percent in Caxiuanã FLONA (Lisboa \& Nazaré 1997, Ilkiu-Borges and Lisboa 2002, Lisboa \& Osakada 2005, Alvarenga et al. 2007, Ilkiu-Borges et al. 2009, 2013, Moraes \& Lisboa 2009, Oliveira \& ter Steege 2013, Cerqueira et al. 2015). According to (Gradstein et al. 2001), the climatic conditions of Humid Tropical Forests favor the exuberant proliferation of bryophytes, which confirms the number of species recorded in the present survey.

Bryophyte density gradually increased along the disturbance stages (stages I, II and III). Similar findings were found in other groups such as edaphic macrofauna, where a linear increase in density was observed in a chronosequence (Amazonas et al. 2018). Interestingly, the number of occurrences recorded in stages II and III was higher than that in primary forest (Stage IV).

The richness of species recorded in secondary forests differed from other studies in forests with a history of perturbation, in which richness of secondary forests was lower than of primary forests (6 to 13 less species) (Ilkiu-Borges \& Lisboa 2002, 
Tavares-Martins et al. 2014, Fagundes et al. 2016). In the present study, even if the Stage II had more species than stages III and IV, and the later two were equivalent in number of species, there was no significant difference.

Thus, both density and richness throughout the stages studied are not in line with the hypothesis that there is an intermediate period of the ecological succession process in which these parameters are higher than in mature forest (Peet 1995) and support the results found by Holz \& Gradstein (2005), which indicated that Species richness of cryptogamic epiphytes in secondary and primary forests of the Cordillera de Talamanca, Costa Rica were nearly the same, showing that primary forests are not necessarily more diverse than secondary forests.

The lowest density (53 occurrences) and richness (29 species) values were observed in Stage I, where plots sampled the most recently disturbed sites (0-10 years). However, although environmental disturbances may have led to a large loss of bryophyte diversity (Newmaster et al. 2003), the number of species recorded in Stage I was only 17 percent less than of that of primary forests. For some authors, the suppression of vegetation cover in tropical America has resulted in species loss rates between 30 and 50 percent (Sillett et al. 1995, Acebey et al. 2003). According to Massoca et al. (2012), the occurrence of disturbed areas inside still conserved forests may have influenced the maintenance of the number of species.

\section{Species composition}

As microenvironmental conditions may significantly influence species composition along a vertical gradient (Oliveira \& ter Steege 2015, Oliveira \& Oliveira 2016), it is believed that microenvironmental conditions can influenced the composition of species recorded throughout the successional stages as well.
Early succession typically exposes species to more intense solar radiation, leading to a selection of desiccation tolerant taxa (Ariyanti et al.2008), such as Frullania spp. and Pycnolejeunea spp. For this reason, this successional stage has a peculiar group of species that differs from the other stages. The same pattern of dominance of species tolerant to high solar incidence in early ecological succession has been reported in vascular plants (Chazdon 2008). The occurrence of canopy specialists, according to Oliveira and ter Steege (2013), in stage I as Frullania caulisequa (Nees) Nees, contiguous Pycnolejeunea (Nees) Grolle, Caudalejeunea lehmanniana (Gottsche) A. Evans demonstrates that the opening of the forest structure allows some typical canopy bryophytes to occur in areas of lesser height.

With respect to vascular plants, the regeneration process gives way to a gradual increase in number of species and functional complexity (Chazdon 2012, Vieira et al. 2014). This was also observed in the bryophytes. In relation to Stage I, Stage II presented higher density and richness and a significantly different composition of species. Compared to Stage I, the number and frequency of species with ocelli had an increase of 32 percent (27 occurrences) and 28 percent ( 4 spp.), respectively. Species such as Ceratolejeunea confusa R.M. Schust., Ceratolejeunea guianensis (Nees \& Mont.) Steph., Ceratolejeunea minuta Dauphin and Ceratolejeunea laetefusca (Austin) R.M. Schust., which have ocelli in their leaves, began to occur in Stage II. According to He et al. (2013), the oil bodies contained in the ocelli may have the function of protecting against excessive light, ultraviolet radiation and desiccation.

In this study, the bryophyte composition over 25 years of regeneration (Stage III) resembled that of primary forests (Stage IV), with unapparent differences between these stages. The period of recolonization of secondary forests by primary 
forest taxa varies across biological groups. In the case of edaphic macrofauna in tropical forests, this process takes between 7 and 8 years post-disturbance (Medeiros 2016, Amazonas et al. 2018). Epiphytic macrolichens, on the other hand, were reported not having yet recovered their original diversity in a shrubbery forest after 40 years of regeneration in a tropical montane forest (Benitez et al. 2012). According to Massoca et al. (2012), the successional trajectory can be influenced by several factors, among them the creation of disturbed sites inside conserved forests. The availability of dispersing agents may have also contributed to the regeneration of the bryophyte flora in the studied environments.

\section{Bioindicator species}

Although Stage I hosted a lower density and richness of species, Archilejeunea auberiana (Mont.) A.Evans., Acrolejeunea torulosa (Lehm. \& Lindenb.) Schiffn. and Acrolejeunea emergens (Mitt.) Steph. presented higher fidelity and specificity to the environmental conditions in this stage. Classified as sun tolerant epiphytes, these species have morphological characteristics that provide them a high capacity to withstand environmental conditions that cause desiccation (Gradstein 1994). Among their morphological characteristics, a lobule size varying from $2 / 5$ to $1 / 2$ of the length of the leaf when fully developed, and pigmentation varying from green to reddish brown or dark brown are typical in these genera (Gradstein 1994, Zartman and Ilkiu-Borges 2007). The lobules are structures that serve for water storage and the red pigmentation of the cells is intended to protect the chlorophyll and DNA from possible damage caused by ultraviolet radiation (Zartman 2003, Glime 2017).

In contrast to the findings of Zartman (2003), who considered epiphyllous bryophytes an ideal group to describe the impacts of habitat fragmentation due to their high sensitivity to local environmental conditions, Cololejeunea subcardiocarpa Tixier was classified as an indicator of 10- to 25-year old secondary forests as suggested by its higher fidelity and specificity to these environments, even though there were one to two occurrences in the other stages.

Prionolejeunea denticulata (Weber) Schiff., Prionolejeunea muricato-serrulata (Spruce) Steph., Haplolejeunea cucullata (Steph.) Grolle and Radula flaccida Lindenb. \& Gottsche were classified as indicators of Stage IV, occurring exclusively in primary forests with the exception of Haplolejeunea cucullata (Steph.) Grolle, which had one record in Stage II. Radula flaccida Lindenb. \& Gottsche, a generalist species, was described by Zartman (2003) as abundant in small forest fragments (1 to $10 \mathrm{ha}$ ) in central Amazonia. The other species were classified as shade tolerant epiphytes and according to Frahm et al. (2003) they are good indicators of primary forests due to their high vulnerability to disturbance, disappearing when forest coverage is destroyed.

\section{Guilds of tolerance to solar radiation}

In environments with a history of disturbance, generalist species are usually less affected and have large occurrences at all successional stages (Acebey et al. 2003), being the guild of tolerance predominate in this study and in the studies developed by Garcia et al. (2014a), Pantoja et al. (2015) and Fagundes et al. (2016). Unlike ordinary ones, species with a more restricted niche such as sun and shade tolerant taxa were more negatively affected by habitat loss (Alvarenga et al. 2010).

According to Proctor et al. (2007), bryophytes found in open and exposed sites have extreme levels of tolerance both to desiccation and intense solar radiation, which also applies to the sun epiphytes that were most representative in Stage I. With the structural development of disturbed forests, sun tolerants are replaced by species adapted to understory conditions 
of mature forests, resulting in a better representation of this guild in Stage IV (Benitez et al. 2015).

\section{Substrate colonization}

Abundance over 70 percent of corticicolous species is commonly found in the Brazilian Amazon, since live bark is the most available substrate for colonization of bryophytes (Valente et al. 2009). As mature forests have decomposing wood residues with higher moisture content than those in newly altered forests, epixylic bryophytes are better established in the later stages of ecological succession (Haughian \& Frego 2015).

According to Pedroso-Junior et al. (2008), the practice of cutting and burning vegetation is very recurrent among small farmers in the Amazon region. These practices erode the soil. In fact, terrestrial bryophytes were found mainly in Stage I in the present study. In later stages, the litter layer formed hinders the establishment of these species (Valente et al. 2009). The preparation of the soil by burning vegetation leaves residues such as coal to become a habitat for colonization by some bryophytes. This explains the occurrence of bryophytes on this substrate only in successional stages with a history of disturbance.

A study with epiphyllous bryophytes reported their preference for moist and shaded environments (Gradstein et al. 2001). In hostile environments such as small forest fragments (1 to 10 ha), epiphylls occur abundantly but are represented by significantly fewer species than continuous forests (Zartman 2003). In the present study, the epiphylls that occurred in Stage II presented occurrence close to that of primary forests (30\% and 38\%, respectively). We observed that the palm tree leaves were the most colonized, mainly in secondary forests. (Edwards 1986) mentioned that palm tree leaves offer microhabitats capable of providing excellent conditions for the establishment of bryophytes in altered environments.

\section{CONCLUSIONS}

Composition of species was the variable that best contributed to understanding the distribution of bryophyte communities throughoutthe successional stages. Secondary forests with a recent history of disturbance (0 to 10 years of regeneration) had the most distinct group of bryophytes in comparison to mature forest, while 25 years of regeneration led to a more similar composition to that of primary forest.

The different stages of ecological succession were marked by eight indicator species except stage III, which there were no species with fidelity and specificity to the environmental conditions in this stage.

Species with a wide range of tolerance (generalists) predominated in all successional stages and there was a decrease in the richness of sun tolerants and increase in the richness of shade tolerants as the stages advanced.

We believe that the land use history and land cover can influence the availability and quality of substrates. Thus, epixylic species were better represented in late successional stages, terrestrial ones in initial stages, and the colonization of coal was typical of secondary forests. Furthermore, in the case of epiphylls, palm tree leaves possibly promoted their higher occurrence in the initial successional stages.

\section{REFERENCES}

ACEBEY A, GRADSTEIN SR \& KRÖMER T. 2003. Species richnesS and habitat diversification of bryophytes in submontane rain forest and fallows of Bolivia. J Trop Ecol 19: 9-18.

ALVARENGA LDP, LISBOA RCL \& TAVARES ACC. 2007.Novas referências de hepáticas (Marchantiophyta) da Floresta 
Nacional de Caxiuanã para o Estado do Pará, Brasil. Acta Bot Brasilica 21: 649-656.

ALVARENGA LDP, PÔRTO KC \& OLIVEIRA JRPM. 2010. Habitat loss effects on spatial distribution of non-vascular epiphytes in a Brazilian Atlantic forest. Biodivers Conserv 19: 619-635.

AMAZONAS NT, VIANI RAG, REGO MGA, CAMARGO FF, FUJIHARA RT \& VALSECHI OA. 2018. Soil macrofauna density and diversity across a chronosequence of tropical forest restoration in Southeastern Brazil. Brazilian J Biol 78: 1-8.

ARIYANTI NS, BOS MM, KARTAWINATA K, TJITROSOEDIRDJO SS, GUHARDJA E \& GRADSTEIN SR. 2008. Bryophytes on tree trunks in natural forests, selectively logged forests and cacao agroforests in Central Sulawesi, Indonesia. Biol Conserv 141: 2516-2527.

BENITTEZ A, PRIETO M \& ARAGON G. 2015. Large trees and dense canopies: Key factors for maintaining high epiphytic diversity on trunk bases (bryophytes and lichens) in tropical montane forests. Forestry 88: 521-527.

BENITTEZ Á, PRIETO M, GONZÁLEZ Y \& ARAGÓN G. 2012. Effects of tropical montane forest disturbance on epiphytic macrolichens. Sci Total Environ 441: 169-175.

BRASIL. 1961. Decreto n²39, de 28 de novembro de 1961. Brasilia: ICMBIO.

BUCK WR. 2003. Guide to the plants of Central French Guiana. part 3. Mosses. Mem N Y Bot Gard 76: 1-167.

CARVALHO-SILVA M, STECH M, SOARES-SILVA LH, BUCK WR, WICKETT NJ, LIU Y \& CÂMARA PEAS. 2017. A molecular phylogeny of the Sematophyllaceae s.l. (Hypnales) based on plastid, mitochondrial and nuclear markers, and its taxonomic implications. Taxon 66: 811-831.

CERQUEIRA GR, BORGES ALI, MANZATTO AG \& MACIEL S. 2015. Briófitas de Um Fragmento de Floresta Ombrófila Aberta no Município de Porto Velho e Novas Ocorrências para Rondônia, Brasil. Biota Amaz 5: 71-75.

CHAZDON RL. 2008. Chance and Determinism in Tropical Forest Succession. In: Carson WP \& Schnitzer SA (Eds), Tropical Forest Community Ecology, Oxford: WileyBlackwell, p. 384-408.

CHAZDON RL. 2012. Regeneração de florestas tropicais. Bol do Mus Para Emílio Goeldi Ciências Nat 7: 195-218.

CORNELISSEN JHC \& TER STEEGE H. 1989. Distribution and ecology of epiphytic bryophytes and lichens in dry evergreen forest of Guyana. J Trop Ecol 5: 131-150.

COSTA DP \& PERALTA DF. 2015. Briófitas in Lista de Espécies da Flora do Brasil [Online]. http://reflora.jbrj.gov.br/ jabot/floradobrasil/FB128472 [1 May 2017].
CRANDALL-STOTLER B, STOTLER RE \& LONG DG. 2009. Morphology and classification of the Marchantiophyta. In: Shaw AJ \& Goffinet B (Eds), Bryophyte Biology, Cambridge: University Press Cambridge, p. 1-54.

DAUPHIN G. 2009. Ceratolejeunea (Lejeuneaceae: Lejeuneoideae). Flora Neotrop Monogr 90: 1-80.

DUFRÊNE M \& LEGENDRE P. 1997. Species assemblages and indicator species: the need for flexible asymmetrical approach. Ecol Monogr 67: 345-366.

EDWARDS ME. 1986. Disturbance histories of four snowdonian woodlands and their relation to Atlantic bryophyte distributions. Biol Conserv 37: 301-320.

FAGUNDES DN, TAVARES-MARTINS ACC, ILKIU-BORGES AL, MORAES E DE NR \& SANTOS RCP. 2016. Riqueza e aspectos ecológicos das comunidades de briófitas (Bryophyta e Marchantiophyta) de um fragmento de Floresta de Terra Firme no Parque Ecológico de Gunma, Pará, Brasil. Iheringia 71: 72-84.

FRAHM J-P, O'SHEA B, PÓCS T, KOPONEN T, PIIPPO S, ENROTH J, RAO P \& FANG Y-M. 2003. Manual of tropical bryology. Trop Bryol 23: 1-196.

GARCIA E, TAVARES-MARTINS ACC \& FAGUNDES DN. $2014 \mathrm{a}$. Diversidade florística de briófitas da reserva ecológica do Bacurizal, Salvaterra, Itha de Marajó, Pará, Brasil. Enciclopédia Biosf 19: 2168-2182.

GARCIA ET, ILKIU-BORGES AL \& TAVARES-MARTINS ACC. 2014b. Brioflora de duas florestas de terra firme na Área de Proteção Ambiental do Lago de Tucuruí, PA, Brasil. Hoehnea 41: 499-514.

GLIME JM. 2007. Economic and Ethnic Uses of Bryophytes. Flora North Am North 27: 14-41.

GLIME JM. 2017. Economic and ethnic uses of bryophytes. In: Glime JM (Ed), Bryophyte Ecology, Houghton: Bryologists, Michigan Technological University and the G-1 International Association, p. 1-25.

GOFFINET B, BUCK WR \& SHAW AJ. 2009. Morphology, anatomy, and classification of the Bryophyte. In: Shaw JA \& Goffinet B (Eds), Bryophyte Biology, Cambridge: University Press Cambridge, p. 55-138.

GRADSTEIN SR. 1992. The vanishing tropical rain forest as an environment for bryophytes and lichens. In: Bates JW \& Farmer AM (Eds), Bryophytes and liches in a changing enviroment. Oxford: Clarendon Press, p. 234-258.

GRADSTEIN SR. 1994. Lejeuneaceae: Ptychantheae, Brachiolejeuneae. New York: The New York Botanical Garden Press. 
GRADSTEIN SR, CHURCHILL SP \& SALAZAR AN. 2001. Guide to the bryophytes of Tropical America. Mem N Y Bot Gard 86: 1-577.

GRADSTEIN SR \& COSTA DP. 2003. The Hepaticae and Anthocerotae of Brazil. Mem N Y Bot Gard 87: 1-196.

GRADSTEIN SR \& ILKIU-BORGES AL. 2009. Liverworts and hornworts. In: Buck WR \& Daniel TF (Eds), Guide to the plants of central french Guiana. New York: Memoirs of the New York Botanical Garden.

HAMMER O, HARPER DAT \& RYAN PD. 2013. PAST: Paleontological Statistic software package for education and data analysis. Paleontol Eletronica 4: 1-9.

HAUGHIAN SR \& FREGO KA. 2015. Synthetic logs for controlled culture of epixylic bryophytes: log physical properties, microclimatic control, and Dicranum flagellare growth. Evansia 32: 158-170.

HE X, SUN Y \& ZHU RL. 2013. The Oil Bodies of Liverworts: Unique and Important Organelles in Land Plants. CRC Crit Rev Plant Sci 32: 293-302.

HOLZ I \& GRADSTEIN RS. 2005. Cryptogamic epiphytes in primary and recovering upper montane oak forests of Costa Rica - species richness, community composition, and ecology. Plant Ecology 178: 89-109.

ILKIU-BORGES AL \& LISBOA RCL. 2002. Lejeuneaceae (Hepaticae). In: Pedro LBL (Ed), Caxiuanã: populações tradicionais, meio físico e diversidade biológica, Belém: Museu Paraense Emílio Goeldi, p. 399-420.

ILKIU-BORGES AL, LISBOA RCL \& MORAES ENR. 2009. AvançOS no conhecimento da brioflora. In: Pedro LBL (Ed), Caxiuanã: desafios para a conservação de uma Floresta Nacional na Amazônia, Belém: Museu Paraense Emílio Goeldi, p. 313-330.

ILKIU-BORGES AL, MACÊDO LPC, PEREIRA MAV \& LISBOA RCL. 2013. Briófitas em Caxiuanã: Resultados do Levantamento em duas parcelas da Grade do PPBIO. In: Pedro LBL (Ed), Caxiuanã: Paraíso Preservado, Belém: Museu Paraense Emílio Goeldi, p. 287-295.

LEGENDRE P \& LEGENDRE LFJ. 2012. Numerical Ecology. $3^{\text {rd }}$ ed. Amsterdam: Elsevier.

LESICA P, MCCUNE B, COOPER S V \& HONG WS. 1991. Differences in lichen and bryophyte communities between oldgrowth and managed second-growth forests in the Swan Valley, Montana. Can J Bot 69: 1745-1755.

LISBOA PLB. 2013. Caxiuanã: paraíso ainda preservado. Belém: Museu Paraense Emílio Goeldi.

LISBOA PLB, BEZERRA MGF \& CARDOSO ALR. 2013. Caxiuanã: conservação, riscos e possibilidades. In: Pedro LBL (Ed), Caxiuanã: paraíso ainda preservado, Belém: Museu Paraense Emílio Goeldi, p. 29-42.
LISBOA RCL \& NAZARÉ JMM. 1997. A flora briológica. In: Pedro LBL (Ed), Caxiuanã, Belém: Museu Paraense Emílio Goeldi, p. 221-233.

LISBOA RCL \& OSAKADA A. 2005. O Gênero Vitalianthus R.M. Schust. \& Giancotti (L ejeuneaceae), no estado do Pará. Bol do Mus Para Emilio Goeldi Ciencias Nat 1: 45-48.

MACHADO S, CYSNEIROS V, NASCIMENTO RG, MARTINS A \& SCHMIDT L. 2017. Projeção da Estrutura Diamétrica de Grupos Ecológicos em uma Floresta Ombrófila Mista. Floresta Ambient 24:1-10.

MASSOCA PES, JAKOVAC ACC, BENTOS TV, WILLIAMSON GB \& MESQUITA RCG. 2012. Dinâmica e trajetórias da sucessão secundária na Amazônia central. Bol do Mus Para Emilio Goeldi Ciencias Nat 7: 235-250.

MEDEIROS PSD. 2016. Indicadores ambientais para funcionalidade ecológica em florestas secundárias de diferentes idades na Amazônia oriental. Tese de Doutorado, Universidade Federal do Pará.

MORAES ENR \& LISBOA RCL. 2009. Diversidade, taxonomia e distribuição por estados brasileiros das famílias Bartramiaceae, Brachytheciaceae, Bryaceae, Calymperaceae, Fissidentaceae, Hypnaceae e Leucobryaceae (Bryophyta) da Estação Científica Ferreira Penna, Caxiuanã, Pará, Brasil. Acta Amaz 39: 773-791.

NEWMASTER SG, BELLAND RJ, ARSENAULT A \& VITT DH. 2003. Patterns of bryophyte diversity in humid coastal and inland cedar hemlock forests of British Columbia. Environ Rev 11: 159-185.

OLIVEIRA HC \& OLIVEIRA SM. 2016. Vertical distribution of epiphytic bryophytes in Atlantic Forest fragments in northeastern Brazil. Acta Botanica Brasilica 30: 609-617.

OLIVEIRA SM \& TER STEEGE H. 2013. Floristic overview of the epiphytic bryophytes of terra firme forests across the Amazon basin. Acta Bot Brasilica 27: 347-363.

OLIVEIRA SM \& TER STEEGE H. 2015. Bryophyte communities in the Amazon forest are regulated by height on the host tree and site elevation. J Ecol 103: 441-450.

PANTOJA ACC, ILKIU-BORGES AL, TAVARES-MARTINS ACC \& GARCIA ET. 2015. Bryophytes in fragments of Terra Firme forest on the great curve of the Xingu River, Pará state, Brazil. Braz J Biol 75: 238-249.

PEDROSO-JUNIOR NN, ADAMS C \& MURRIETA RSS. 2008. A agricultura de corte e queima: um sistema em transformação. Bol Mus Para Emílio Goeldi 3: 153-174.

PEET RK. 1995. Community structure and ecosystem function. In: Glein-Lewin DC, Peet RK \& Veblen TT (Eds), 
Plant Succession: theory and prediction, edited by. London: Chapman \& Hall, p. 103-151.

PROCTOR MCF, OLIVER MJ, WOOD AJ, ALPERT P, STARK LR, CLEAVITT NL \& MISHLER BD. 2007. Desiccation-tolerance in bryophytes: a review. Bryologist 110: 595-621.

REINER-DREHWALD ME. 2000. Las Lejeuneaceae (Hepaticae) de Misiones, Argentina VI. Lejeunea y Taxilejeunea. Bryophyt Divers Evol 19(1): 1-50.

RICHARDS PW. 1984. The Ecology of tropical forest bryophytes. In: Schuster RM (Ed), New manual of bryology, Nichinan: Hattori Botanical Laboratory, p. 1233-1270.

ROBBINS RG. 1952. Bryophyta ecology of a dune area in New Zealand. Acta Geobotânica 4:1-31.

SALOMÃO RPS, VIEIRA ICG, BRIENZA JÚNIOR S, AMARAL DD \& SANTANA AC. 2012. Sistema Capoeira Classe: uma proposta de sistema de classificação de estágios sucessionais de florestas secundárias para o estado do Pará. Bol do Mus Para Emilio Goeldi Ciencias Nat 7: 297-317.

SANTOS ND, COSTA DP, KINOSHITA LS \& SHEPHERD GJ. 2011. Aspectos brioflorísticos e fitogeográficos de duas formações costeiras de Floresta Atlântica da Serra do Mar, Ubatuba/SP, Brasil. Biota Neotrop 11: 425-438.

SILLETT SC, GRADSTEIN SR, GRIFFIN D \& GRIFFIN D. 1995. Bryophyte Diversity of Ficus Tree Crowns from Cloud Forest and Pasture in Costa Rica. Bryologist 98: 251-260.

TAVARES ACC. 2009. Florística e Ecologia das Comunidades de Briófitas em Florestas de Terra Firme no Estado do Pará, Amazônia, Brasil. Tese de Doutorado. Rio de Janeiro, Instituto de Pesquisas Jardim Botânico do Rio de Janeiro/Escola Nacional de Botânica Tropical.

TAVARES-MARTINS ACC, CÉLIA R, LISBOA L \& PINHEIRO D. 2014. Bryophyte flora in upland forests at different successional stages and in the various strata of host trees in northeastern Pará, Brazil. Acta Bot Brasilica 28: 46-58.

VALENTE EDB, PÔRTO KC, BÔAS-BASTOS SBV \& BASTOS CJP. 2009. Musgos (Bryophyta) de um fragmento de Mata Atlântica na Serra da. Acta Bot Brasilica 23: 369-375.

VIEIRA ICG \& GARDNER TA. 2012. Florestas secundárias tropicais: ecologia e importância em paisagens antrópicas. Bol Mus Para Emilio Goeldi Ciencias Nat 7: 191-194.

VIEIRA ICG, GARDNER T, FERREIRA J, LEES AC \& BARLOW J. 2014. Challenges of governing second-growth forests: A case study from the Brazilian Amazonian state of Pará. Forests 5: $1737-1752$.
YANO O. 1984. Briófitas. In: Fidalgo O \& Bononi VLR (Eds), Técnicas de coleta, preservação e herborização de material botânico, São Paulo: Instituto de Botânica, p. 27-30.

ZAR JH. 2009. Biostatistical analysis. New Jersey: Prentice Hall.

ZARTMAN CE \& ILKIU-BORGES AL. 2007. Guide to the Epiphyllous Bryophytes of Central Amazonia. Manaus: Instituto Nacional de Pesquisas da Amazônia.

ZARTMAN CE. 2003. Habitat fragmentation impacts on epiphyllous bryophyte communities in central Amazonia. Ecology 84: 948-954.

\section{How to cite}

TAKASHIMA-OLIVEIRA TTG, MEDEIROS PS \& TAVARES-MARTINS ACC. 2020. Bryophyte communities across the ecological succession process in the Caxiuanã National Forest, Pará, Brazil. An Acad Bras Cienc 92: e20180626. DOI 10.1590/0001-3765202020180626.

Manuscript received on June 27, 2018; accepted for publication on November 27, 2018

\section{TÁSSIA T.G. TAKASHIMA-OLIVEIRA}

https://orcid.org/0000-0002-2526-5510

\section{PRISCILA S. DE MEDEIROS}

https://orcid.org/0000-0002-5001-9573

\section{ANA CLÁUDIA C. TAVARES-MARTINS}

https://orcid.org/0000-0003-4972-036X

Universidade do Estado do Pará, Tv. Dr. Enéas Pinheiro, 2626, Bairro Marco, 66095-015 Belém, PA, Brazil

Correspondence to: Tássia Toyoi Gomes Takashima-Oliveira E-mail: tassiatka@gmail.com

\section{Author contributions}

This research was derived from the master's work of the first author. The main idea of the article came from supervisors Priscila Sanjuan and Ana Cláudia Tavares-Martins. Thus, writing, collection, identification and interpretation of data were conducted by Tássia Takashima-Oliveira. The data analysis was developed with the most effective collaboration of Priscila Sanjuan. And, collection, textual review, theoretical guidance and discussion by Ana Cláudia Tavares-Martins.

(cc) BY 